Afr. J. Trad. CAM (2005) 2 (2): 129 - 133

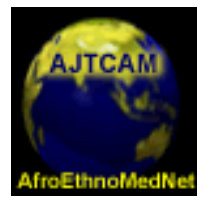

Research Paper Afr. J. Traditional, Complementary and Alternative Medicines www.africanethnomedicines.n

ISSN 0189-6016@2005

\title{
ANTICESTODAL EFFICACY OF FOLKLORE MEDICINAL PLANTS OF NAGA TRIBES IN NORTH-EAST INDIA
}

\author{
Temjenmongla and Arun Kumar Yadav* \\ Department of Zoology, North-Eastern Hill University, \\ Shillong 793022, India \\ Email: akynehu@hotmail.com
}

\begin{abstract}
The anticestodal efficacy of nine plants that are used in the indigenous system of medicine by Naga tribes in north-east India to cure intestinal-helminth parasitic infections was tested employing Raillietina echinobothrida, a tapeworm of poultry, as a model test parasite. The study revealed that the leaves of Psidium guajava, Houttuynia cordata and stalk of Lasia spinosa possess a profound anticestodal efficacy as evident by the mean mortality time of $R$. echinobothrida which ranged from 1 to $3.66 \mathrm{hrs}$, following exposure to $5-40 \mathrm{mg} / \mathrm{ml}$ concentration of these plant extracts. Moderate activity was recorded for the leaves of Clerodendrum colebrookianum, Lasia spinosa and Centella asiatica, while Curcuma longa, Cinnamomum cassia, Gynura angulosa, Lasia spinosa (stem) and Aloe vera revealed a negligible degree of anticestodal activity.
\end{abstract}

Keywords: Anticestodal Efficacy, Naga Tribes, India, Raillietina echinobothrida.

\section{Introduction}

The traditional medicines hold a great promise as source of easily available effective anthelmintic agents to the people, particularly in tropical developing countries, including India. It is in this context that the people consume several plants or plant-derived preparations to cure helminthic infections (Akerele, 1990; Satyavati, 1990). The origin of many effective drugs is found in the traditional medicine practices and in view of this several workers have undertaken studies pertaining to testing of folklore medicinal plants for their proclaimed anthelmintic efficacy (Yadav et al., 1992; Roy and Tandon, 1999; Sukul et al., 1999; Al-Qarawi et al., 2001; Githiori et al., 2002; Tangpu and Yadav, 
Afr. J. Trad. CAM (2005) 2 (2): 129 - 133

2003; Tangpu et al., 2004). Investigations on the anthelmintic activity of plants namely Mallotus phillippensis lam, Cardiospermum halicacabum, Ocimum sanctum, Trifolium repens, have revealed them to be significantly efficacious against helminth parasites infections (Singh et al., 1997; Khunkitti et al., 2000; Asha et al., 2001; Tangpu and Yadav, 2004). In the present study we report the anticestodal efficacy of some folklore medicinal plants of Naga tribes in north-east India, using Raillietina echinobothrida, a tapeworm of poultry, as a model test parasite.

\section{Materials and Methods}

\section{Preparation of Plant Extracts:}

The plants that were tested for their anticestodal activity are listed in Table 1 . The selection of these plants was made on the basis of information gathered about their use in the traditional medicine system by local traditional healers in the Nagaland state. The plant materials were collected from different places in Nagaland State and duly identified by Dr. Y. Kumar, Plant Taxonomist, Department of Botany, NEHU, Shillong. A voucher specimen of each plant was deposited in the herbarium collection at Department of Zoology, NEHU, Shillong. The plant materials were dried under shade, grounded into powdered form and extracted with ethanol and ethyl acetate (Curcuma longa) using Soxhlet extractor (Gafner et al., 1985). The extract was concentrated in vacuo and the residue was dried over anhydrous calcium chloride and stored at $-4^{0} \mathrm{C}$ until use.

\section{Testing of Plant Extracts:}

Live specimens of adult $R$. echinobothrida were collected in $0.9 \%$ phosphate buffered saline (PBS, $\mathrm{pH}$ 7.3) from intestines of freshly necropsied domestic fowl (Gallus gallus domesticus L.). The test parasites were maintained in Hank's solution at $37 \pm 2^{\mathrm{O}} \mathrm{C}$ inside an incubator. The plant extracts were dissolved in a few drops of $1 \%$ Dimethyl Sulphoxide (DMSO), and tested at 5, 10, 20 and $40 \mathrm{mg} / \mathrm{ml}$ concentrations. In each case, a set of worms maintained without plant extract but having a few drops of $1 \%$ DMSO in Hank's solution served as negative controls. The anticestodal efficacy of plant extracts was adjudged in terms of the motility and mortality of the test parasites and was monitored at regular time-intervals. The mortality of parasites was confirmed by removing the plantextract treated/control parasites from Hank's solution and dipping them in slightly warm water. The mortality of parasite was assumed to have occurred when all signs of movements had ceased.

\section{Results and Discussion}

Table 2 summarizes the effects of plant extracts on mortality time of test parasite, $R$. echinobothrida. The worms incubated in the control medium showed physical activity 
Afr. J. Trad. CAM (2005) 2 (2): 129 - 133

for about 69.00 hours. The mean survival time of the reference praziquantel-treated worms recorded for 5 and $10 \mathrm{mg} / \mathrm{ml}$ concentrations was 2.34 and $1.67 \mathrm{hrs}$, whereas the same was

Table 1: List of plants tested for anticestodal efficacy.

$\begin{array}{llll}\text { Plant } & \text { Family } & \text { Local name } & \text { Plant part tested } \\ \text { Species } & & \end{array}$

\begin{tabular}{|c|c|c|c|}
\hline $\begin{array}{l}\text { 1. Houttuynia cordata Thumb } \\
\text { Voucher No. (AKY/003) }\end{array}$ & Piperaceae & Mokma & Leaves \\
\hline $\begin{array}{l}\text { 2. Lasia spinosa Linn } \\
\text { Voucher No. (AKY/002) }\end{array}$ & Araceae & Jurang & Leaves, stalk, stem \\
\hline $\begin{array}{l}\text { 3. Centella asiatica Linn } \\
\text { Voucher No. (AKY/004) }\end{array}$ & Apiaceae & Longsokorok & Leaves \\
\hline $\begin{array}{l}\text { 4. Clerodendrum } \\
\text { colebrookianum Walp } \\
\text { Voucher No. (AKY/005) }\end{array}$ & Verbenaceae & Orema & Leaves \\
\hline $\begin{array}{l}\text { 5. Gynura angulosa DC } \\
\text { Voucher No. (AKY/006) }\end{array}$ & Asteraceae & Ensu & Leaves \\
\hline $\begin{array}{l}\text { 6. Aloe vera Linn } \\
\text { Voucher No. (AKY/007) }\end{array}$ & Liliaceae & Aing naro & Leaves \\
\hline $\begin{array}{l}\text { 7. Psidium guajava Linn } \\
\text { Voucher No. (AKY/001) }\end{array}$ & Myrtaceae & Modiram & Leaves \\
\hline $\begin{array}{l}\text { 8. Curcuma longa Linn } \\
\text { Voucher No. (AKY/008) }\end{array}$ & Zingiberaceae & Nakong & Rhizomes \\
\hline $\begin{array}{l}\text { 9. Cinnamomum cassia Presl } \\
\text { Voucher No. (AKY/009) }\end{array}$ & Lauraceae & Shingja & Bark \\
\hline
\end{tabular}

found to be 1.34 and 0.84 hrs for 20 and $40 \mathrm{mg} / \mathrm{ml}$ concentrations. Out of different plant extracts tested, $P$. guajava, $H$. cordata and $L$. spinosa (stalk) showed a profound anticestodal activity as revealed by the mean mortality time of parasites which varied between 1.00 to 3.66 hrs as compared to the standard drug PZQ where it varied between 0.84 to 2.34 hrs. The extracts of C. colebrookianum, L. spinosa (leaves) and C. asiatica showed a moderate level of efficacy as adjudged by mean mortality time of parasites which ranged from 4 to 14.66 hrs (Table 2). However, the mean mortality time of test parasite in case of treatment with extracts of C. longa, C. cassia, G. angulosa, L. spinosa (stem) and A. vera varied from 6.00 to 67.00 hrs. In a related study on medicinal plants of Naga tribes, we also observed an equally comparable efficacy of leaf extract of P. guajava, C. asiatica and L. spinosa (stalk) against a filarial parasite, Setaria cervi 
Afr. J. Trad. CAM (2005) 2 (2): $129-133$

Table 2: Anticestodal efficacy of plant extracts against R. echinobothrida, in vitro.

\begin{tabular}{|c|c|c|c|c|}
\hline \multirow[t]{2}{*}{$\begin{array}{l}\text { PLANT/PLANT } \\
\text { PARTS }\end{array}$} & \multicolumn{4}{|c|}{$\begin{array}{l}\text { Mean mortality time of } R \text {. echinobothrida at different } \\
\text { concentrations of plant extract }\end{array}$} \\
\hline & $5 \mathrm{mg} / \mathrm{ml}$ & $10 \mathrm{mg} / \mathrm{ml}$ & $20 \mathrm{mg} / \mathrm{ml}$ & $40 \mathrm{mg} / \mathrm{ml}$ \\
\hline Psidium guajava (leaves) & $2.00 \pm 0.00$ & $2.00 \pm 1.00$ & $1.00 \pm 0.00$ & $1.00 \pm 0.00$ \\
\hline Houttuynia cordata (leaves) & $3.00 \pm 0.00$ & $3.00 \pm 1.00$ & $3.00 \pm 1.73$ & $2.00 \pm 0.00$ \\
\hline Lasia spinosa (stalk) & $3.66 \pm 0.57$ & $2.33 \pm 0.57$ & $2.00 \pm 1.00$ & $2.00 \pm 1.00$ \\
\hline $\begin{array}{l}\text { Clerodendrum } \\
\text { colebrookianum (leaves) }\end{array}$ & $9.00 \pm 1.73$ & $7.00 \pm 2.60$ & $4.00 \pm 0.00$ & $4.00 \pm 1.00$ \\
\hline Lasia spinosa (leaves) & $13.00 \pm 1.00$ & $7.66 \pm 1.52$ & $5.30 \pm 2.51$ & $4.33 \pm 0.57$ \\
\hline Centella asiatica (leaves) & $14.66 \pm 1.15$ & $9.00 \pm 1.00$ & $6.00 \pm 2.00$ & $5.00 \pm 1.73$ \\
\hline Curcuma longa (leaves) & $20.00 \pm 3.00$ & $14.70 \pm 1.50$ & $7.30 \pm 2.50$ & $6.00 \pm 0.00$ \\
\hline Cinnamomum cassia (bark) & $24.70 \pm 0.60$ & $20.00 \pm 2.00$ & $14.00 \pm 4.40$ & $8.70 \pm 2.10$ \\
\hline Gynura angulosa (leaves) & $38.00 \pm 1.00$ & $36.30 \pm 0.60$ & $34.00 \pm 0.00$ & $34.00 \pm 2.00$ \\
\hline Lasia spinosa (stem) & $41.00 \pm 0.00$ & $30.00 \pm 2.64$ & $20.66 \pm 1.15$ & $14.00 \pm 1.00$ \\
\hline Aloe vera (leaves) & $67.00 \pm 3.60$ & $51.70 \pm 3.10$ & $42.00 \pm 0.57$ & $37.00 \pm 1.00$ \\
\hline PRAZIQUANTEL & $2.34 \pm 0.58$ & $1.67 \pm 0.76$ & $1.34 \pm 0.29$ & $0.84 \pm 0.29$ \\
\hline CONTROL* & & & & \\
\hline
\end{tabular}

*Data represent mean values \pm SD of mortality (h) for eleven experiments

(Temjenmongla and Yadav, 2003). In contrast, unlike in the present study the efficacy of $H$. cordata was found to be quite insignificant against $S$. cervi. This indicates that the anticestodal efficacy of plants differs with respect to different groups of helminth parasites. In conclusion, the results indicate that of the various plants used in folk-medicine system of Naga tribes to "cure" helminthic infections not all possess the anticestodal efficacy as acclaimed by the people. 
Afr. J. Trad. CAM (2005) 2 (2): 129 - 133

\section{Acknowledgement}

Partially financial support under the University Grants Commission's DRS-III Programme in the Department of Zoology, NEHU, Shillong to carry out this study is gratefully acknowledged.

\section{References}

1. Akerele, O. (1990). Medicinal Plants in Traditional Medicine. In: Farnsworth, N. R. and Wagner, H. (eds.). Economic and Medicinal Plant Research. Vol. 4. Plants and Traditional Medicine. Academic Press Ltd., London.

2. Al-Qarawi, A. A., Mahmoud, O. M., Sobaih, H. E. M. and Adam, S. E. (2001). A preliminary study on the anthelmintic activity of Calotropis procera latex against Haemonchus contortus infection in Najdi sheep. Vet. Res. Commun., 25:61 - 70.

3. Asha, M. K., Prashanth, D., Murali, B., Padmaja, R. and Amit, A. (2001). Anthelmintic activity of essential oil of Ocimum sanctum and eugenol. Fitoterapia.72: 669 -79.

4. Gafner, F., Msonthi, J. D. and Hostettmann, K. (1985). Molluscicidal saponins from Talinum tenuissimum Dinter. Helvet. Chim. Acta. 68: 555- 558.

5. Githiori, J. B., Hoglund, J., Waller, P. J. and Baker, R. L. (2002). Anthelmintic activity of preparations derived from Myrsina africana and Rapanea melanophloeos against the nematode parasite, Hoemonchus contortus, of sheep. J. Ethnopharmacol., 80: 187-191.

6. Khunkitti, W., Fujimaki, Y. and Aoki, Y. (2000). In vitro antifilaricidal activity of extracts of the medicinal plant Cartiospermum helicacabum against Brugia phangi. J. Helminthol., 74: 241-246.

7. Roy, B. and Tandon, V. (1999). Flukicidal activity of Alpinia nigra (Zingerberaceae) against the trematode, Fasciolopsis buski, in humans. Biomed. Letters. 60: 23-29.

8. Satyavati, G. V. (1990). Use of plant drugs in Indian Traditional Systems of Medicine and their Relevance to Primary Health Care. In: Farnsworth, N. R. and Wagner, H. (eds.). Economic and Medicinal Plant Research. Vol. 4. Plants and Traditional Medicine. Academic Press Ltd., London.

9. Singh, R., Singhal, K. C. and Khan, N. U. (1997). Antifilarial activity of Mallotus philippensis lam of S. cervi (Nematoda: Filariodea) in vitro. Indian J. Physiol. Pharmacol. 41: 397-403.

10. Sukul, N. C., Sarkar, P., Sukul, A. and Sinhababu, S. P. (1999). Antifilarial effect of Artemesia nilagirica extract and its ultra high dilutions against Canine Dirofilariasis. Jap. J. Trop. Med. Hyg., 27: 477-481.

11. Tangpu, V. and Yadav, A. K. (2003). In vitro filaricidal activity of some folklore medicinal plants of Manipur, India. In: Gupta, N. and Gupta, D. K. (eds.). Parasites and Diseases. Neeraj Publisher, Bareilly, pp. 127-132.

12. Tangpu, V. and Yadav, A. K. (2004). Anticestodal activity of Trifolium repens extract. Pharmaceutical Biol., 42: 1-3.

13. Temjenmongla, Yadav, A. K. (2003). Filaricidal efficacy of some folklore medicinal plants against Setaria cervi (Nematoda: Filarioida). Proc. Zool. Soc. Calcutta. 56: 57-61.

13. Yadav, A. K., Tandon, V. and Rao, H. S. P. (1992). In vitro anthelmintic efficacy of fresh tuber extract of Flemingia vestita against Ascaris suum. Fitoterapia. 63: 395-398. 